\title{
Comparative effect of anti-inhibin and eCG-hCG supplementation on reproductive hormonal profile in virgin cycling female rats.
}

\author{
Alsaadi, J.A.A. ${ }^{1}$, Al-Okaily, B.N. ${ }^{2}$, Al-shwilly, H.A.J. ${ }^{3}$ \\ ${ }^{1}$ Physiology, Dept. Physiol. \& Pharmacol., College Vet. Med., Al-Qadisiya Univ, Iraq. Mobile: +964-780- \\ 1156473. Email: jbr20042002@yahoo.com \\ ${ }^{2}$ Physiology, Dept. Physiol. \& Pharmacol., College Vet. Med., Baghdad Univ, Iraq. \\ ${ }^{3}$ Dept. Anim. Resources, College of Agric., Sumer Univ., Iraq.
}

\section{Received:- 21/11/2015}

Accepted:-26/1/2016

\begin{abstract}
To examine the effect of anti-inhibin and hCG-eCG treatments on reproductive hormonal profile in virgin cycling female rats, fifty four virgin cyclic female rats, aged 56 days and weighted 150-170 g., were randomly assigned to three equal groups (AI, eCG, and control). At late metaestrus and $54 \mathrm{~h}$

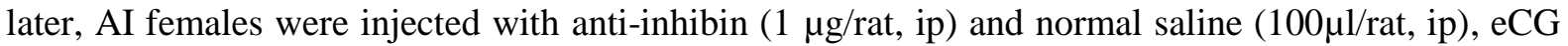
females were injected with equine chorionic gonadotropin (20 IU/rat, ip) and human chorionic

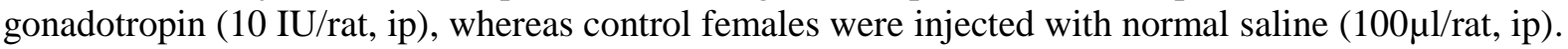
Eighteen females from each group were sacrificed after treatment (6 females/ group every $12 \mathrm{~h}$ for three times). Blood samples were obtained for hormonal assay (FSH, LH, estradiol 17B, prolactin, and ir-inhibin B). Serum FSH concentration of AI females increased significantly than other other groups throughout all periods. Also control females recorded significant elevation compared with eCG females. Serum LH concentrations registered no significant differences between AI and C groups, but they were significantly higher than eCG group only after $36 \mathrm{~h}$. of treatment. Serum prolactin concentrations showed significant decline in AI group among experimental groups throughout all periods. Inhibin B levels, after 12, 24, and $36 \mathrm{~h}$ of treatment, decreased significantly in AI group compared with other groups. 17B-estradiol concentrations recorded insignificant differences among groups after $12 \mathrm{~h}$. of treatment, while after $24 \mathrm{~h}$., AI group level increased significantly than other groups. After $36 \mathrm{~h}$. of treatment, AI and eCG groups recorded insignificant difference between each other, but, they were significantly higher than control. It can be concluded that anti-inhibin treatment increases the reproductive fecundity in female rats
\end{abstract}

Key words: anti-inhibin, eCG, fertility, reproductive hormones.

\section{Physiology Classification Qp-(981)345}

*This research adapted from the doctoral thesis of the third researcher 


\section{Introduction}

such as mice (4), rats (5), hamsters (6), cows (7), and mares (8). Early onset of puberty (time of first ovulation) was observed after immunization early with an inhibin-enriched bovine follicular fluid preparation (9). Immunoneutralization against endogenous inhibin has been used to enhance oocyte development (10), and accelerate puberty in immature female rats $(5,11)$. The present study aimed to examine the role of passive immunization against inhibin alpha subunit and eCG-hCG treatment at late metaestrus on reproductive hormonal profile in virgin cycling female rats.

\section{Material and methods}

females) have been administered with ip injection of eCG (20 IU/ rat), dissolved in 100 $\mu \mathrm{l}$ of distilled water, at late metaestrus. After $54 \mathrm{~h}$ (at proestrus), females have been injected with 10 IU hCG. Control group (18 females) have been administered with ip injection of normal saline $(100 \mu \mathrm{l} / \mathrm{rat})$, at late metaestrus and after $54 \mathrm{~h}$ (at proestrus). After 12, 24, and 36 hours (during estrus cycle), 6 females from each group have been sacrificed each time, and blood samples have been obtained in nonheparinized centrifuge tubes. Blood sera were separated and stored at $-20{ }^{\circ} \mathrm{C}$ until hormonal assay. Hormonal concentrations (FSH, LH, estradiol 17B, prolactin, and ir-inhibin B) were assessed using ELISA technique. Anti-inhibin alpha that used in the present study was obtained as purified antibody (monoclonal antibody) at a concentration of $200 \mu \mathrm{g} / \mathrm{ml}$.

\section{Results}

$(p \leq 0.05)$ compared with control throughout the three experimental periods. In comparison between periods for each group, the differences reached its peak after $36 \mathrm{~h}$ of treatment in all groups.
Inhibin, a glycoprotein hormone produced by the granulosa cells in the ovarian follicles suppresses the production and secretion of pituitary gonadotropins, particularly FSH through negative feedback mechanism, as well as its participation in the regulation of ovarian folliculogenesis through autocrine and/or paracrine control (1). Passive immunization against inhibin raised FSH secretion in the phase of the estrous cycle with high estradiol secretion (follicular phase) (2) or with high progesterone secretion (mid-luteal phase) (3). Multiple ovulations were encouraged effectively by endogenous inhibin immunoneutralization in a number of species

Animals: Adult virgin cycling female rats of Wistar strain (aged 56 days; and weighted 150-170 g.) have been born at the animal house of the College of Veterinary Medicine, Al-Qadisiya University, and used in the present study. They were kept under controlled day light (12L: 12D cycles) and temperature $\left(22-24{ }^{\circ} \mathrm{C}\right)$ with access to standard laboratory food (19\% protein ratio and 3000 kilocalories energy) and drinking water ad libitum. The females were identified by tail labeling. Vaginal smears have been checked daily and only female rats with at least two consecutive 4-5 day cycles have been used.

Experimental design: fifty four female rats have been assigned into three equal groups (AI, eCG, and control). AI group (18 females) have been administered a single ip injection of inhibin antiserum $(1 \mu \mathrm{g} /$ rat $)$, dissolved in 100 $\mu \mathrm{l}$ of distilled water, at late metaestrus. After $54 \mathrm{~h}$ (at proestrus), females have been injected

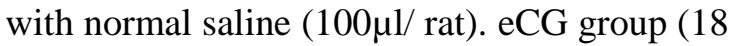

FSH: serum FSH (IU/L) increased significant $(\mathrm{p} \leq 0.05)$ after $12 \mathrm{~h}$ of AI treatment compared with other groups, and continued after 24 and $36 \mathrm{~h}$ of treatment (figure 1), whereas eCG treated group showed significant decline 


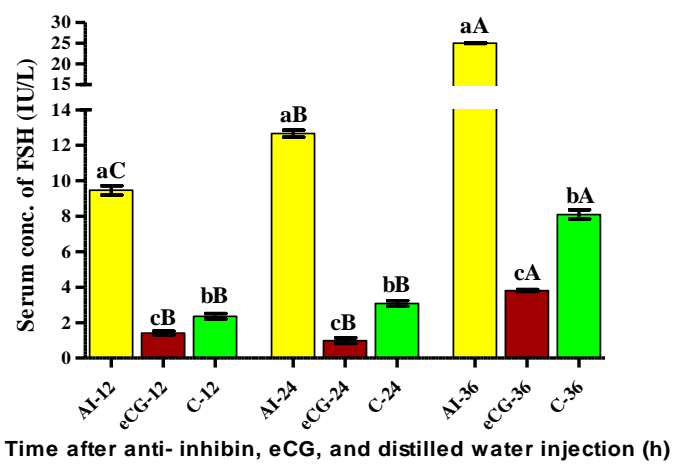

Figure (1): Serum FSH concentrations (IU/L) in AI and eCG treated female rats.

h. Data were presented as Mean \pm SD of 6 observations $(n=6)$. Different small litters denote significant difference $(\mathrm{p} \leq 0.05)$ between groups for each period. Different capital letters denote significant difference $(\mathrm{p} \leq 0.05)$ between periods for each group.

comparison between the experimental periods $(12,24$, or 36 hrs. after treatment) for each group, the statistical analysis showed that all groups recorded the significant $(\mathrm{p} \leq 0.05)$ highest levels after $36 \mathrm{~h}$ of treatment in comparison with that recorded after 12 and 24 $\mathrm{h}$ of treatment, which showed no significant $(p \geq 0.05)$ differences when compared with each other (figure 2).

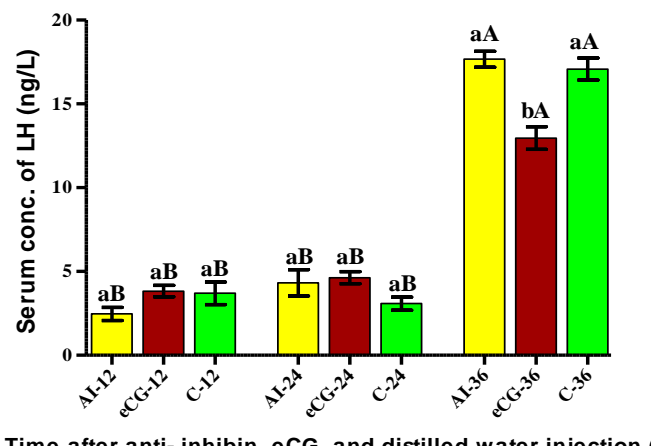

Figure (2): Serum LH concentrations (ng/L) in AI and eCG treated female rats.

observations $(\mathrm{n}=6)$. Different small litters denote significant difference $(p \leq 0.05)$ between groups for each period. Different capital letters denote significant difference $(\mathrm{p} \leq 0.05)$ between periods for each group.

\footnotetext{
Time after anti- inhibin, eCG, and distilled water injection (h)
}

AI: female rats injected with $1 \mu \mathrm{g}$ of $\mathrm{AI} / 100 \mu \mathrm{l}$ of $\mathrm{dw} / \mathrm{rat}$ ip, at late metaestrus and $100 \mu \mathrm{l}$ of $\mathrm{dw}$ ip after 54h. eCG: female rats injected with $20 \mathrm{IU}$ of $\mathrm{eCG} / 100 \mu \mathrm{l}$ of $\mathrm{dw} / \mathrm{rat}$ ip, in late metaestrus and $10 \mathrm{IU}$ of hCG/100 $\mu \mathrm{l}$ of $\mathrm{dw} / \mathrm{rat}$ ip, after 54 h. C: female rats injected with 100 $\mu \mathrm{l}$ of $\mathrm{dw} / \mathrm{rat}$ ip, in late metestrus and after 54

LH: the results of serum $\mathrm{LH}$ concentration $(\mathrm{ng} / \mathrm{L})$ in virgin cyclic female rats showed no significant $(\mathrm{p} \geq 0.05)$ differences between groups after 12 and $24 \mathrm{~h}$ of treatment, when compared with each other. After $36 \mathrm{~h}$ of treatment, AI treated and control females recorded no significant $(\mathrm{p} \geq 0.05)$ difference, but they were significantly $(\mathrm{p} \leq 0.05)$ higher than that registered by eCG treated females. In
AI: female rats injected with $1 \mu \mathrm{g}$ of $\mathrm{AI} / 100 \mu \mathrm{l}$ of dw/rat ip, at late metaestrus and $100 \mu \mathrm{l}$ of dw ip after 54h. eCG: female rats injected with $20 \mathrm{IU}$ of $\mathrm{eCG} / 100 \mu \mathrm{l}$ of $\mathrm{dw} / \mathrm{rat} i p$, in late metaestrus and $10 \mathrm{IU}$ of hCG/100 $\mu \mathrm{l}$ of dw /rat ip, after $54 \mathrm{~h} . \mathrm{C}$ : female rats injected with $100 \mu \mathrm{l}$ of $\mathrm{dw} /$ rat $i p$, in late metestrus and after $54 \mathrm{~h}$. Data were presented as Mean \pm SD of 6 
periods. Statistical analysis among periods, for AI treated group, showed significant $(p \leq 0.05)$ decline of serum prolactin concentration with time. In eCG treated and control females, the decline was significant $(\mathrm{p} \leq 0.05)$ in both 24 and $36 \mathrm{~h}$. periods in comparison with $12 \mathrm{~h}$ period, but they showed no significant difference $(p \geq 0.05)$ when compared with each other.

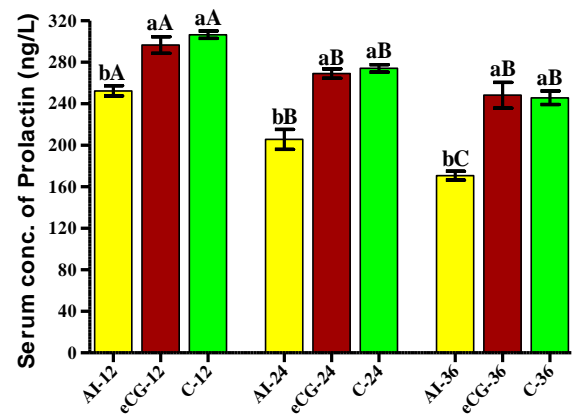

Time after anti- inhibin, eCG, and distilled water injection (h)
Prolactin: serum concentrations of prolactin $(\mathrm{ng} / \mathrm{L})$ in virgin cyclic female rats, clarified in figure (3), revealed significant $(\mathrm{p} \leq 0.01)$ lower concentrations in AI treated females compared among experimental groups at all periods

$(12,24$, and $36 \mathrm{~h}$ after treatment), whereas eCG treated and control females recorded no significantly $(\mathrm{p} \geq 0.05)$ differences in their serum prolactin concentrations at the same

Figure (3): Serum prolactin concentrations (ng/L) in AI and eCG treated female rats.

eCG treated and control females at all periods, whereas eCG treated and control females recorded no significant $(\mathrm{p} \geq 0.05)$ differences after 12 and $24 \mathrm{~h}$ of treatment but they differ significantly $(\mathrm{p} \leq 0.05)$ after $36 \mathrm{~h}$ of treatment, where control level was higher than eCG treated level. In comparison between periods $(12,24$, and $36 \mathrm{~h})$ for each group, ir-inhibin-B concentration of AI group recorded significant $(\mathrm{p} \leq 0.05)$ gradual decrease with time progressing to be more significant $(\mathrm{p} \leq 0.001)$ at $36 \mathrm{~h}$ period. In contrast, eCG treated females showed no significant $(\mathrm{p} \geq 0.05)$ difference treatment, but at $36 \mathrm{~h}$ period increased significantly $(\mathrm{p} \leq 0.05)$.

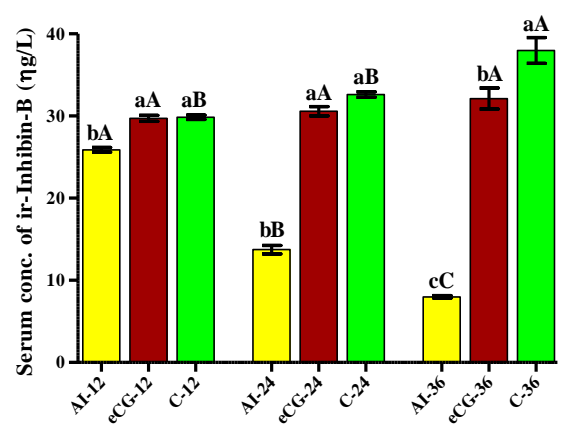

Time after anti- inhibin, eCG, and distilled water injection (h)

AI: female rats injected with $1 \mu \mathrm{g}$ of $\mathrm{AI} / 100 \mu \mathrm{l}$ of dw/rat $i p$, at late metaestrus and $100 \mu \mathrm{l}$ of dw ip after 54h. eCG: female rats injected with $20 \mathrm{IU}$ of eCG/100 $\mu \mathrm{l}$ of $\mathrm{dw} / \mathrm{rat} i p$, in late metaestrus and $10 \mathrm{IU}$ of hCG/100 $\mu \mathrm{l}$ of dw /rat ip, after $54 \mathrm{~h}$. C: female rats injected with $100 \mu \mathrm{l}$ of $\mathrm{dw} /$ rat $i p$, in late metestrus
AI: female rats injected with $1 \mu \mathrm{g}$ of $\mathrm{AI} / 100 \mu \mathrm{l}$ of dw/rat $i p$, at late metaestrus and $100 \mu \mathrm{l}$ of dw ip after 54h. eCG: female rats injected with $20 \mathrm{IU}$ of $\mathrm{eCG} / 100 \mu \mathrm{l}$ of $\mathrm{dw} / \mathrm{rat} i p$, in late metaestrus and $10 \mathrm{IU}$ of hCG/100 $\mu \mathrm{l}$ of dw /rat ip, after $54 \mathrm{~h} . \mathrm{C}$ : female rats injected with $100 \mu \mathrm{l}$ of $\mathrm{dw} /$ rat $i p$, in late metestrus and after $54 \mathrm{~h}$. Data were presented as Mean $\pm \mathrm{SD}$ of 6 observations $(n=6)$. Different small litters denote significant difference $(\mathrm{p} \leq 0.05)$ between groups for each period. Different capital letters denote significant difference $(\mathrm{p} \leq 0.05)$ between periods for each group.

Ir-Inhibin-B: figure (4) illustrates the results of serum ir-inhibin-B concentrations $(\mathrm{ng} / \mathrm{L})$ in virgin female rats after 12,24 , and $36 \mathrm{~h}$ of treatment. AI treated females revealed significant $(\mathrm{p} \leq 0.05)$ decline compared with after 12,24 , and $36 \mathrm{~h}$ of treatment, whereas control females registered no significant $(\mathrm{p} \geq 0.05)$ difference between 12 and $24 \mathrm{~h}$ of

\footnotetext{
Figure (4): Serum ir-inhibin B concentrations $(\mathrm{ng} / \mathrm{L})$ in $\mathrm{AI}$ and eCG treated female rats.
} 
estradiol concentrations in $\mathrm{AI}$ and eCG treated females showed no significant $(p \geq 0.05)$ difference between each other, but they were significantly $(\mathrm{p} \leq 0.05)$ higher than control concentration. In comparison between periods $(12,24$, and $36 \mathrm{~h})$ for each groups, the concentration of AI treated group at $36 \mathrm{~h}$ was significantly $(\mathrm{p} \leq 0.05)$ higher than that of other periods (12 and $24 \mathrm{~h}$ ), which showed no significantly $\quad(p \geq 0.05) \quad$ difference when compared with each other. Estradiol levels of other female rats (control and eCG treated groups) recorded significant $(\mathrm{p} \leq 0.05)$ decrease at $24 \mathrm{~h}$ period compared with that of $12 \mathrm{~h}$ period, but they recorded further significant $(p \leq 0.05)$ increase at $36 \mathrm{~h}$ period.

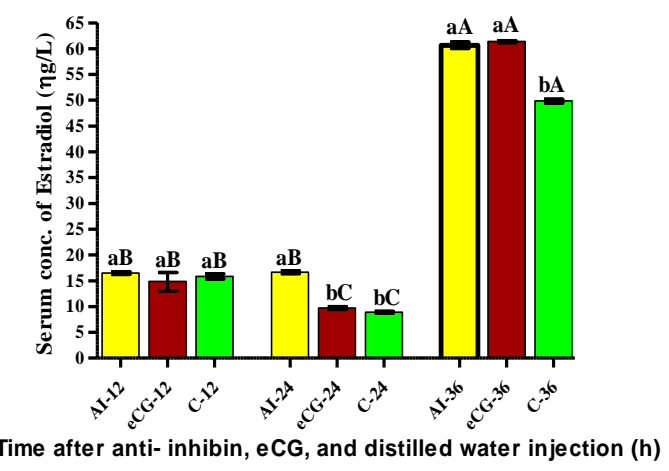

this decrease accompanied by rapid increase of serum FSH and rapid decrease of prolactin concentrations (after 12 hours of treatment) and delayed increase of serum estradiol-17 $\beta$ concentrations (after 24 hours of treatment).

The decrement of serum inhibin-B concentration could allow activins to perform its action on pituitary gonadotrophs to secrete more FSH because inhibins and activins are functionally antagonistic members of the evolutionarily conserved $\mathrm{TGFb}$ family of extracellular signaling molecules (14).Scientific studies revealed that inhibin regulates FSH secretion by reducing the amount of activin available at the binding site and also by reducing activin binding with activin type II receptors (15). Activin binding to its receptors has been shown to increase FSH secretion (16), thus supposed our results where serum FSH concentration was significantly increased rapidly after 12 hours of AI treatment. Increased FSH concentration along with increased estradiol-17 $\beta$ is perhaps the main reason for the improved reproductive and after $54 \mathrm{~h}$. Data were presented as Mean \pm SD of 6 observations $(n=6)$. Different small litters denote significant difference $(\mathrm{p} \leq 0.05)$ between groups for each period. Different capital letters denote significant difference $(\mathrm{p} \leq 0.05)$ between periods for each group.

Estradiol-17B: the results of serum estradiol concentrations (ng/L) in virgin female rats, clarified in figure (5), revealed no significant $(\mathrm{p} \geq 0.05)$ differences among experimental groups after $12 \mathrm{~h}$ of treatment, while $24 \mathrm{~h}$ period recorded significant $(\mathrm{p} \leq 0.05)$ decline of serum estradiol concentration in eCG treated and control female rats compared with that recorder by $\mathrm{AI}$ treated females, where eCG treated and control groups showed no significant $(\mathrm{p} \geq 0.05)$ difference when compared with each other. After $36 \mathrm{~h}$ of treatment, serum

\section{Figure (5): $\quad$ Serum estradiol-17B concentrations (ng/L) in AI and eCG treated female rats.}

AI: female rats injected with $1 \mu \mathrm{g}$ of $\mathrm{AI} / 100 \mu \mathrm{l}$ of $\mathrm{dw} / \mathrm{rat} i p$, at late metaestrus and $100 \mu \mathrm{l}$ of $\mathrm{dw}$ ip after $54 \mathrm{~h}$. eCG: female rats injected with $20 \mathrm{IU}$ of eCG/100 $\mu \mathrm{l}$ of $\mathrm{dw} / \mathrm{rat} i p$, in late metaestrus and $10 \mathrm{IU}$ of hCG/100 $\mu 1$ of dw /rat ip, after $54 \mathrm{~h} . \mathrm{C}$ : female rats injected with $100 \mu \mathrm{l}$ of $\mathrm{dw} / \mathrm{rat} i p$, in late metestrus and after $54 \mathrm{~h}$. Data were presented as Mean \pm SD of 6 observations $(n=6)$. Different small litters denote significant difference $(p \leq 0.05)$ between groups for each period. Different capital letters denote significant difference $(p \leq 0.05)$ between periods for each group.

\section{Discussion}

In virgin cycling female rats, AI treatment caused rapid significant decline of serum inhibin-B concentrations after 12 hours of treatment which continued in their decrease after 24, and 36 hours of treatment in comparison with that recorded by eCG treated and control females. This decrement could be attributed to immunoneutralization of endogenous inhibin caused by infusion of inhibin alpha antiserum. These results were in agreement with that reported previously by Abdulla (12) and Thanoon (13). In contrast, 
accompanied by a decrease in plasma levels of FSH as observed previously $(19,20)$. Our results indicate that stimulation of follicular development by administration of eCG was thought to induce an increase in plasma inhibin, which in turn suppress FSH secretion. Basal serum LH levels increased after 36 hours in AI and eCG treated females. This could be due to immunoneutralization of endogenous inhibin, as reported previously (6, $21,22)$ and to eCG-hCG-treatment, which may be attributed to the cross reaction of exogenous eCG in the present $\mathrm{LH}$ receptors (LHRIA), which is in agreement with a previous study (23).

The present study reported decline of serum prolactin and elevation of estradiol-17 $\beta$ concentrations, as FSH secretion increased. The opposite correlation between estradiol-17 $\beta$ and prolactin concentrations may be attributed to the feedback role of estradiol on hypothalamus. Several studies support the hypothesis that hypothalamic AT1 receptors participate in the ovarian steroid feedback on prolactin secretion. The number of AT1 receptors in the arcuate nucleus is inversely related to prolactin secretion, which they are low during proestrus (low estradiol concentration) and highest at estrus (high estradiol concentration) and confined to the dorsomedial portion of the arcuate nucleus where the cell bodies of the TIDA system are located (24).

It can be concluded that passive immunization against endogenous inhibin alpha subunit in virgin female rats, at late metastrus phase of estrus cycle, significantly increases the reproductive efficiency by modulate the reproductive hormonal profile compared with eCG-hCG treatment.

\section{References}

and Hasegawa, Y., (1993). Evidence that inhibin is an important factor in the regulation of FSH secretion during the mid-luteal phase in cows. . J Endocrinol 35-41.

4. Wang, H.C., Herath, G.X., Watanabe, G., and Taya, K., (2001). Superovulation, fertilization and in vitro embryo development in mice after administration of an inhibinneutralizing antiserum. Reproduction, 122, 809-816. efficiency seen in the current study which may potentially reflected on pituitary gland functions (14).

In comparison with eCG treated and control female rats, serum concentration of estradiol$17 \beta$ in the AI treated female rats increased significantly after 24 hours and continued after 36 hours of treatment. This marked increment of estrogen levels occurred in concomitant with the notable growth of a large number of ovarian follicles in AI treated females after 24 hours and those treated with eCG after 36 hours compared with control group, as it has been found that passive immunization of female rats against inhibin alpha subunit increased folliculogenesis as well as Graffian and total follicle number (5). These results clearly indicate that passive immunization against inhibin alpha subunit enhances biosynthesis of estrogens from ovarian follicles.

The improvement of immunoneutralization of female rat's endogenous inhibin, in the present study, was the significant elevation of serum FSH concentration along with that of serum estradiol-17 $\beta$. These findings suggest that a high level of endogenous FSH stimulates the wave of follicular development and results in production of a large amount of estradiol-17 $\beta$, which induces the LH surge by positive feedback effect to the hypothalamus and pituitary axis, leading to induction of superovulation. Increased FSH levels in AI treated female rats indicate that endogenous inhibin is a primary factor in the control of species-specific ovulation rate, mainly through the control of FSH secretion, as described previously in many species $(17,18)$.

In addition, treatment with eCG resulted in a dramatic increase in the secretion of inhibin and estradiol-17 $\beta$. These increases were

1. Findley, (1993). An update on the role of inhibin, activin, and follistatin as local regulators of folliculogenesis. Biol Reprod $48,15-23$.

2. Kaneko, H., Nakanishi, Y., Akagi, S., Arai, K., Taya, K., and Hasegawa, S., (1995). Immunoneutralization of inhibin and estradiol during the follicular phase of the estrous cycle in cows. Biol. Reprod., 53, 031-939.

3. Kaneko, H., Nakanishi, Y., Taya, K., Kishi, H., Watanabe, G., Sasamoto, S., 
levels in sequential neonatal inhibinimmunoneutralized female rats. M.Sc. thesis, College of Vet. Med., Al-Qadisiya Univ., Iraq.

14. Miyazono, K., Kamiya, Y., and Morikawa, M., (2010). Bone morphogenetic protein receptors and signal transduction. J. Biochem, 147, 3551.

15. Lewis, K.A., Gray, P.C., Blount, A.L., Macconell, L.A., Wiater, E., Bilezikjian, L.M. and Vale, W., (2000). Betaglycan binds inhibin and can mediate functional antagonism of activin signaling. Nature, 404, 411-414.

16. Lebrun, Chen, Y., and Vale, W., (1997). Receptor serine kinases and signaling by activins and inhibins. In: Aono T, Sugino $\mathrm{H}$, Vale WW (eds) Inhibin, Activin, and Follistatin: Regulatory Functions in System and Cell Biology. SpringerVerlag, New York, 1-20.

17. Taya, (1993). Role of inhibin in regulation of FSH secretion and folliculogenesis in mammalians. Curr Trends Exp Endocrinol, 1, 97-116.

18. Taya, K.,and Watanabe, G., (1999). RE: Inhibin as a key hormone in determining species-specific ovulation rates in mammal. In: Kwon HB, Joss JMP, Ishii S (eds.), Recent Progress in Molecular and Comparative Endocrinology. Hormone Research Center,134-143. Kwangju, Korea.

19. Rivier, C., Rivier, J. and Vale, W. (1986). Inhibin-mediated feedback control of follicle.stimulating hormone secretion in the female rat. Science 234: 205-208.

20. Kishi, Okada, T., Kawazu, S., Otsuka, M., Taya, K., Watanabe, G. and Sasamoto, S., (1997). Effects of passive immunization against estradiol-17b and inhibin on the secretion of gonadotropin in the cyclic golden hamster (Mesocricetus auratus). Reprod. Fertil. Dev., 9, 447-453.

21. Celler, and Negro-Vilar, (1989). Endogenous inhibin suppress only basal follicle-stimulating hormone secretion but suppress all parameters of pulsatile luteinizing hormone secretion in the diestrous female rat. Endocrinology 124, 2944-2953.

22. Arai, Watanabe, G., Taya, K., and Sasamoto, S., (1996). Roles of inhibin and
5. Al-Saaidi, J.A.A., and Samir, M.S., (2010). RE: Effect of passive immunization against inhibin alpha subunit on ovarian growth and development in immature female Wister rats. 14th Scientific Congress of Fac. Med. Assiut Univ. Egypt.

6. Kishi, Okada, T., Otsuka, M., Watanabe, G., Taya, K., and Sasamoto, S., (1996). Induction of superovulation by immunoneutralization of endogenous inhibin through the increase in the secretion of follicle-stimulating hormone in the cyclic golden hamster. $J$ Endocrinol, 151, 65-75.

7. Takedomi, T.H., Kaneko, Y., Aoyagi, K., Konishi, H., Kishi, Watanabe, G., and Taya, K., (1997). Effects of passive immunization against inhibin on ovulation rate and embryo recovery in Holstein heifers. Theriogenology, 47, 1507-1518.

8. Nambo, Y.H., Kaneko, S., Nagata, Oikawa, M., Yoshihara, T. and et. Al., (1998). Effect of passive immunization against inhibin on FSH secretion, folliculogenesis and ovulation rate during the follicular phase of the estrous cycle in mares. Theriogenology, 50, 545-557.

9. Al-Obaidi, S.A.R., Bindon, B.M., Hillard, M.A., and O'shea, T., (1987). Reproductive characteristics of lambs actively immunized early in life with inhibin-enriched preparations from follicular fluid of cows. J. Reprod. Fertil., 81, 403-414.

10. Ishigame, H., Medan, M.S., Wang, H., Watanabe, G., Kishi, H., and Arai, K.Y., (2005). Induction of superovulation by immunoneutralization of endogenous inhibin in immature rats. J. Reprod. Dev., 51, 559-566.

11. Samir, M.S. (2010). Effect of passive immunization against inhibin-alpha subunit on puberty of immature female Wister rats. M.Sc. thesis, College of Vet. Med., Al-Qadisiya Univ., Iraq.

12. Abdulla, W.S., (2013). Sequential postnatal evaluation of pituitary, gonadal and extragonadal GnRH-r, IGF-1, and IGF-2 genes in inhibin-passive immunized female rats. M.Sc. thesis, College of Vet. Med., Al-Qadisiya Univ., Iraq.

13. Thanoon, H.B., (2013). Hypothalamic GHRH and pituitary GH genes expression 
24. Warembourg, Jolivet, A., and Milgrom, E.E., (1989). Immunohistochemical evidence of the presence of estrogen and progesterone receptors in the same neurons of the guinea pig hypothalamus and preoptic area. Brain Res 480, 1-15. estradiol in the regulation of folliclestimulating hormone and luteinizing hormone secretion during the estrous cycle of the rat. Biol Reprod, 55, 127-133.

23. Sugino H, Bousfield G, Moore WJ, Ward D., (1987). Structural studies on equine glycoprotein hormones. Amino acid sequence of equine lutropin beta-subunit. J Biol Chem 262:8603-8609.

\title{
التأثير المقارن لمضاد الانهبين وهرموني eCG-hCG على مستوى الهرمونات التكتثرية في إناث الجرذان الأباكير
}

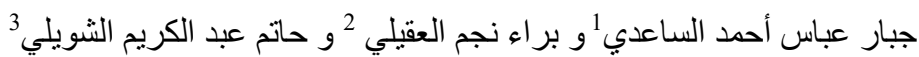

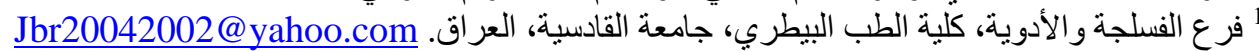

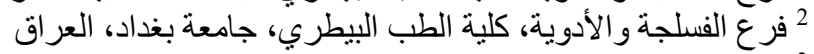

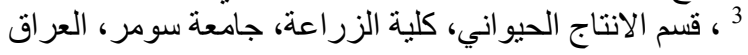

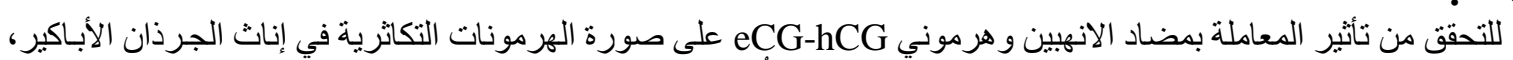

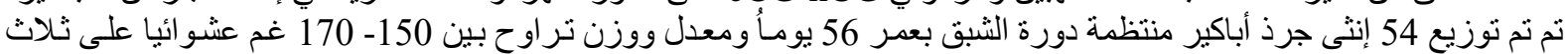

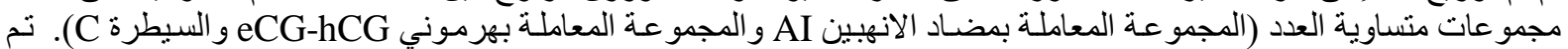

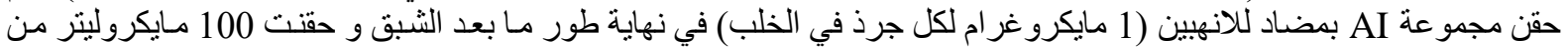

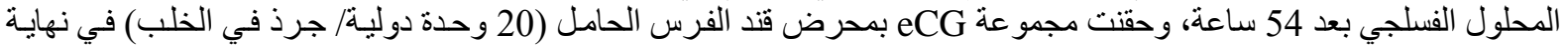

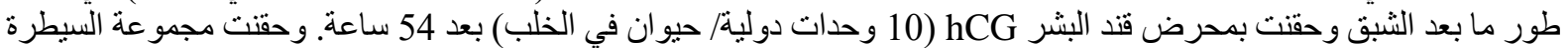

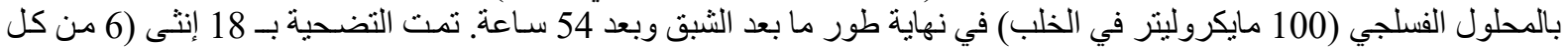

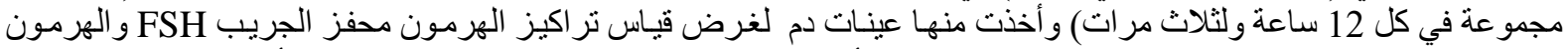

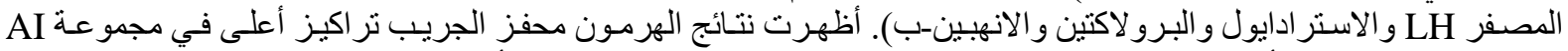

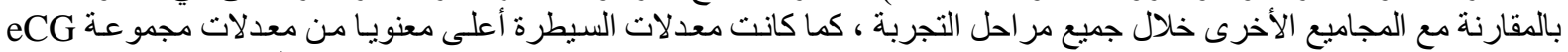

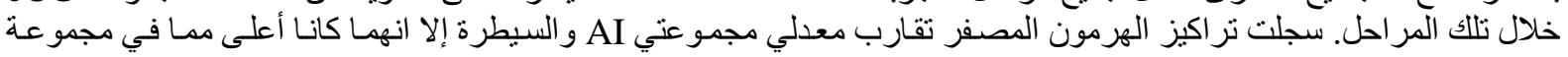
eCG

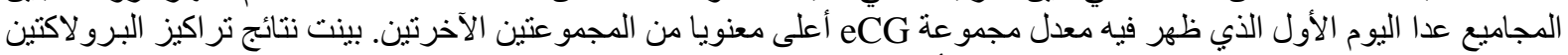

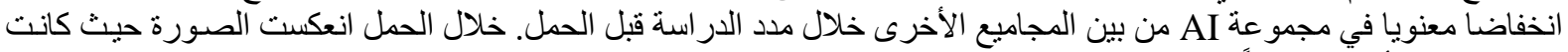

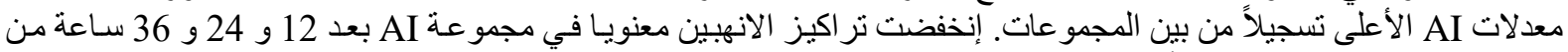

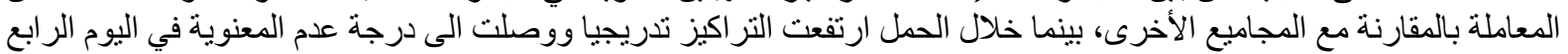

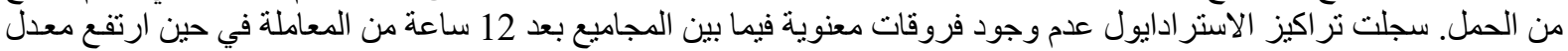

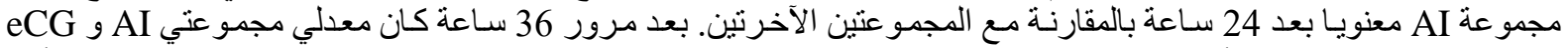

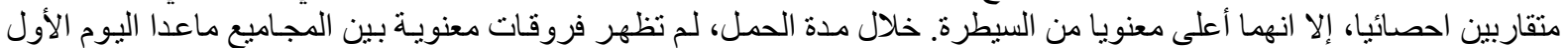

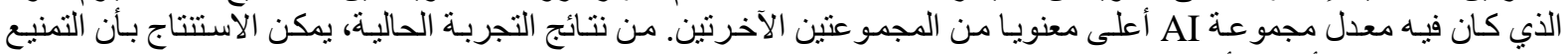
الميسر ضد الانهبين ألفا في أباكير إناث الجرذان يزيد من الكفاءة التكاثرية. 